\title{
АДМИНИСТРАТИВНО-ПРАВОВОЙ ИНСТИТУТ ДЕКЛАРИРОВАНИЯ
}

\begin{abstract}
Аннотация. В статье рассматриваются понятие и признаки нового административно-правового института декларирования. Основные положения рассматриваемого института, многообразие видов деклараџионных отраслевых правоотношений позволяет расширить представление о предмете отрасли административного права. Богатый зарубежной опыт применения методов декларирования свидетельствует об актуальности исследуемой в статье проблематики.
\end{abstract}

Ключевые слова: сравнительное правоведение, декларирование, управление, государство, система, институт, административное, право, виды, понятие

$\mathrm{B}$ опросы правового регулирования сферы государственного управления в Российской Федерации являются одной из актуальных и дискуссионных проблем современности. В условиях проводимых административных преобразований, проблема качества административно-правового регулирования общественных отношений приобретает первостепенное значение. От качества административно-правовой регламентации напрямую зависит успех демократических преобразований в стране.

Развивая институты рыночной экономики, государство идет по пути либерализации, ослабления своего непосредственного участия, контроля и надзора во многих сферах общественной жизни, тем самым позволяя хозяйствующим субъектам и гражданам самостоятельно решать многие вопросы, еще недавно находившиеся в области монопольных интересов государства. Ярким примером этому может служить либерализация административно-правового института лицензирования - количество лицензионных видов деятельности существенно уменьшилось за 10 лет ${ }^{1}$.

Государство все чаще позволяет хозяйствующим субъектам самостоятельно контролировать качество предоставляемых ими услуг или производимых, реализуемых товаров, и как следствие нести за это юридическую ответственность. Даже такая, традиционно подконтрольная государству сфера, как строительство получила с недавних пор возможность к саморегуляции на законодательно установленных условия ${ }^{2}$. Другим примером либерализации контрольных полномочий государства может быть назван администра-

\footnotetext{
1 Федеральный закон от 08.08.2001 №128-Ф3 «О лицензировании отдельных видов деятельности» (ред. от 29.12.2010) / Российская газета, № 153-154, 10.08.2001.

2 Федеральный закон от 01.12.2007 №315-Ф3 «О саморегулируемых организациях» (ред. от 01.07.2011) / Российская газета, №273, 06.12.2007.
}

тивно-правовой институт добровольной сертификации ${ }^{3}$ и так далее.

В условиях интенсивного развития, обновления правовой материи отрасли административного права, неизбежно возникают новые формы и методы правового регулирования, отдельные административно-правовые институты преобразуются, приобретая новое значение в системе институтов отрасли административного права. Указанные обстоятельства становятся предпосылками для формирования новых правовых «образований» - институтов, одним из которых является административно-правовой институт декларирования.

Декларирование как административно-правовой институт в России формировался последовательно на протяжении длительного времени, однако получил свое новое качественное развитие относительно недавно. На сегодня можно с уверенностью говорить, что институт декларирования окончательно вышел за пределы привычного для многих специалистов межотраслевого института налогового или таможенного права, приобрел качества и признаки, характеризующие его как самостоятельный административно-правовой институт.

В первую очередь о таком «преобразовании» свидетельствует появление большого числа разновидностей общественных отношений в сфере декларирования, так можно выделить следующие виды декларирования:

- налоговое ${ }^{4}$;

- таможенное

\footnotetext{
3 Федеральный закон от 27.12.2002 №184-Ф3 (ред. от $28.09 .2010)$ «О техническом регулировании» / Российская газета, №245, 31.12.2002.

4 Раздел V. Налоговый кодекс РФ (часть первая) от 31.07.1998 №146-Ф3 (в ред. от 19.07.2011).

5 Глава 27. Таможенный кодекс Таможенного союза (приложение к Договору о Таможенном кодексе Таможенного союза, принятому Решением Межгосударственного Совета ЕврАзЭС на уровне глав государств от 27.11.2009 №17) (ред. от 16.04.2010) / С3 РФ. 13.12.2010. №50. Ст. 6615.
} 
- декларирование пожарной безопасности

- декларирование соответствия качества продукции (молочной продукции ${ }^{7}$, соковой продукции ${ }^{8}$, табачной продукции ${ }^{9}$, продукции в области генноинженерной деятельности ${ }^{10}$, масложировой продукции $^{11}$, пестицидов и агрохимикатов ${ }^{12}$ ), оказываемых услуг (услуг связи ${ }^{13}$, на железнодорожном транспорте ${ }^{14}$ ), техники (транспортных средств ${ }^{15}$, космической техники $\left.{ }^{16}\right)$;

- декларирование розничной продажи алкогольной продукции ${ }^{17}$;

- декларирование промышленной безопасности ${ }^{18}$;

6 Статья 64. Федеральный закон от 22.07.2008 № 123-Ф3 «Технический регламент о требованиях пожарной безопасности» / Парламентская газета, № 47-49, 31.07.2008.

7 Статья 29. Федеральный закон от 12.06.2008 № 88-Ф3 (ред. от 22.07.2010) «Технический регламент на молоко и молочную продукцию» / С3 РФ. 16.06.2008. № 24. Ст. 2801.

8 Статья 21. Федеральный закон от 27.10.2008 № 178-Ф3 «Технический регламент на соковую продукцию из фруктов и овощей» / Российская газета, №225, 29.10.2008.

9 Статья 14. Федеральный закон от 22.12.2008 № 268-Ф3 «Технический регламент на табачную продукцию» / Российская газета, № 265, 26.12.2008.

10 Статья 11. Федеральный закон от 05.07.1996 № 86-Ф3 (ред. от 19.07.2011) «О государственном регулировании в области генно-инженерной деятельности» / Российская газета, № $130,12.07 .1996$.

11 Статья 22. Федеральный закон от 24.06.2008 № 90-Ф3 «Технический регламент на масложировую продукцию» / Парламентская газета, № 43-44, 03.07.2008.

12 Статья 17. Федеральный закон от 16.07.1998 № 101-Ф3 (ред. от 19.07.2011) «О государственном регулировании обеспечения плодородия земель сельскохозяйственного назначения» / СЗ РФ. 20.07.1998. № 29. ст. 3399.

13 Статья 41. Федеральный закон от 07.07.2003 № 126-Ф3 (ред. от 18.07.2011) «О связи» / СЗ РФ. 14.07.2003. № 28. Ст. 2895.

14 Статья 6. Федеральный закон от 10.01.2003 № 17-Ф3 (ред. от 19.07.2011) «О железнодорожном транспорте в Российской Федерации» / Российская газета, № 8, 18.01.2003.

15 Статьи 5, 15. Федеральный закон от 10.12.1995 № 196-Ф3 (ред. от 19.07.2011) «О безопасности дорожного движения»/ Российская газета, № 245, 26.12.1995.

16 Статья 10. Закон РФ от 20.08.1993 № 5663-1 (ред. от 30.12.2008) «О космической деятельности» / Российская газета, № 186, 06.10.1993.

17 См. Например: Статья 4. Закон Санкт-Петербурга от 07.06.2006 № 287-41 (ред. от 16.07.2010) «Об обороте алкогольной и спиртосодержащей продукции в СанктПетербурге» / СПС Консультант Плюс.

18 Статья 14. Федеральный закон от 21.07.1997 № 116-ФЗ (ред. от 19.07.2011) «О промышленной безопасности опасных производственных объектов» / Российская газета, № 145, 30.07.1997.
- декларирование безопасности гидротехнического сооружения $^{19}$;

- лесное декларирование ${ }^{20}$;

- энергетическое декларирование (декларирование энергопотребления $)^{21}$;

- декларирование объема производства, оборота и (или) использования этилового спирта, алкогольной и спиртосодержащей продукции ${ }^{22}$;

- $\quad$ проектное декларирование ${ }^{23}$.

Анализ нормативных правовых актов, регулирующих указанные виды декларирования, свидетельствует о тесной взаимосвязи рассматриваемого нами института с другими институтами административного права - институтом обращений, сертификации, лицензирования, регистрации, учета, контроля и другими. При этом целый ряд признаков определяет уникальность административно-правового института декларирования. Совокупность данных признаков позволяет сформулировать понятие анализируемого нами правового явления.

Административно-правовой институт декларирования - это совокупность административно-правовых норм, регулирующих общественные отношения, возникающие в связи с уведомлением в нормативно установленном порядке физическими и юридическими лицами уполномоченных органов государственной власти о своих доходах, доходах третьих лиц, о соответствии принадлежащих им денежных средств, вещей, иных материальных объектов или производимых ими товаров, работ или оказываемых услуг, нормативно допустимым качественным и (или) количественным показателям, в целях осуществления внутрихозяйственного и государственного контроля (надзора) в определенных административным законодательством сферах деятельности.

19 Статья 10. Федеральный закон от 21.07.1997 № 117-Ф3 (ред. от 18.07.2011) «О безопасности гидротехнических сооружений» / Российская газета», № 144, 29.07.1997.

20 Статья 26. Лесной кодекс РФ от 04.12.2006 № 200-ФЗ (ред. от 18.07.2011) / Парламентская газета, № 209, 14.12.2006.

21 Статья 11. Закон г. Москвы от 05.07.2006 № 35 «Об энергосбережении в городе Москве» / СПС Консультант Плюс.

22 Статья 14. Федеральный закон от 22.11.1995 № 171-Ф3 (ред. от 21.07.2011) «О государственном регулировании производства и оборота этилового спирта, алкогольной и спиртосодержащей продукции и об ограничении потребления (распития) алкогольной продукции» / Российская газета, № 9, 19.01.1999.

23 Статья 19. Федеральный закон от 30.12.2004 № 214-Ф3 (ред. от 17.06.2010) «Об участии в долевом строительстве многоквартирных домов и иных объектов недвижимости и о внесении изменений в некоторые законодательные акты Российской Федерации» / Парламентская газета, № 5-6, 14.01.2005. 
Рассматриваемый нами в данной статье административно-правовой институт обладает всеми необходимыми для подобного рода правовых категорий признаками:

- нормативно-определенными принципами, регулятивными целями, задачами и функциями правового института;

- разветвленным понятийным аппаратом - декларация, декларирование (декларационный процесс), требования и условия декларирования, декларационный платеж и другие;

- многообразием объектов декларирования;

- уникальным субъектным составом: декларант, декларационный орган;

- специфичностью регулируемых нормами института общественных отношений; наличием особого метода их административно-правового регулирования, который, являясь по своей природе императивным, обладает «уведомительной окраской», что в определенной степени расширяет понимание предмета и метода отрасли административного права.

Зарубежный опыт в рассматриваемой сфере общественных отношений подтверждает актуальность исследования института декларирования. Общее стремление развитых государств повысить эффективность методов государственного управления вызвана потребностями мирового сообщества в улучшении качества жизни, оптимизации взаимодействия государства и гражданина, государства и хозяйствующего субъекта. Основные направления декларирования в России в целом отражают общемировую тенденцию к либерализации и упрощению соответствующих административных (управленческих) процедур.

Вместе с тем, как в России, так и за ее пределами отсутствуют концептуальные исследования правового феномена декларирования, как самостоятельного правового института, объединяющего в рамках своего предмета отношения в самых различных сферах общественной жизни.

В целях более детального исследования особенностей института декларирования и выявления потенциальных возможностей его развития считаем уместным заметить, что зарубежные правовые источники в целом рассматривают декларирование в традиционых для отечественного правоприменителя формах, но с некоторыми особенностями. Так декларирование находит свое отражение в налоговом, таможенном законодательстве стран, в системах оценки и подтверждения качества продукции в форме сертификации Европейского союза, Японии, США.

Процедура декларирования качества - обязательная в России форма подтверждения того, что про- дукция соответствует определенным для нее нормам и стандартам. Это относительно молодая для нашей страны процедура, которая во многом сходна с практикующейся в Европе системой контроля качества продукции.

Показательным на наш взляд является пример совершествования субинститута таможенного декларирования в Японии. В международной таможенной практике электронная форма таможенного декларирования товаров используется с начала восьмидесятых годов двадцатого столетия. При полной автоматизации процедуры производства таможенного оформления, течение сроков измеряется уже не в днях, а в часах и минутах.

Механизм прохождения таможенных формальностей в Японии основан на автоматизированной системе обработки сведений, необходимых для таможенных целей (NACCS), которая подразделяется на воздушную (air-NACCS) и морскую (sea-NACCS). Эта автоматизированная компьютерная система связывает воедино таможенные службы и участников ВЭД.

Декларанту (лицу, подающему заявку на перемещение товара и соответственно его оформление) достаточно со своего рабочего компьютера ввести данные о наименовании товара, стране его изготовления, контрактной стоимости транспортировки и другие необходимые сведения. После этого система в соответствии с действующими ставками таможенных платежей, курсами валют определяет общую сумму, подлежащую уплате за ввозимый товар, и заносит полученные данные в память. Далее заявитель, получив результаты расчетов, имеет возможность еще раз их перепроверить, а также проверить правильность заполненной заявки (декларации), после чего подает команду на исполнение.

Аналогичная система действует и в США. Интересно, что именно американская система АКС (автоматизированная коммерческая система) является прототипом японской. Международный опыт электронного декларирования основан на использовании единых информационных центров, которые используют базы данных оформления, результатов ранее проведенных проверочных мероприятий, содержат информацию об участниках ВЭД. Эти же информационные центры осуществляют работу с рисками, а именно выполняют категоризацию поданных заявок на оформление. Влияние человеческого фактора сведено к нулю, так как система выдает не только рекомендации, но и контролирует их выполнение.

Аналогчичных примеров успешного применения методов декларирования в условиях интенсивного развития информационных технологий достаточно много, и отечественные органы государственного управления 
при поддержке законодательной власти обязаны следовать этой позитивной общемировой тенденции.

Подводя итог, заметим, что гармонично объединяя в себе востребованные сегодня качества большинства административно-правовых институтов, декларирование становится одним из наиболее оптимальных и эффективных механизмов регулирования взаимоотношений между государством и обществом в самых различных сферах общественной жизни.
Затрагиваемая в настоящей статье проблематика, с нашей точки зрения, требует скорейшей научной оценки в рамках самостоятельного детального исследования, что в свою очередь будет способствовать научному обоснованию ключевых положений, характеризующих декларирование как самостоятельный, динамично развивающийся административно-правовой институт и позволит существенно расширить границы предмета регулирования административного права.

\section{Библиографический список:}

1. Федеральный закон от 08.08.2001 № 128-Ф3 «О лицензировании отдельных видов деятельности» (ред. от 29.12.2010) / Российская газета, № 153-154, 10.08.2001.

2. Федеральный закон от 01.12.2007 № 315-Ф3 «О саморегулируемых организациях» (ред. от 01.07.2011) / Российская газета, № 273, 06.12.2007.

3. Федеральный закон от 27.12.2002 № 184-Ф3 (ред. от 28.09.2010) «О техническом регулировании» / Российская газета, № 245, 31.12.2002.

4. Налоговый кодекс РФ (часть первая) от 31.07.1998 № 146-Ф3 (в ред. От 19.07.2011).

5. Таможенный кодекс Таможенного союза (приложение к Договору о Таможенном кодексе Таможенного союза, принятому Решением Межгосударственного Совета ЕврАзЭС на уровне глав государств от 27.11.2009 № 17) (ред. от 16.04.2010) / СЗ РФ. 13.12.2010. № 50. Ст. 6615.

6. Лесной кодекс РФ от 04.12.2006 № 200-Ф3 (ред. от 18.07.2011) / Парламентская газета, № 209, 14.12 .2006$.

7. Федеральный закон от 22.07.2008 № 123-Ф3 «Технический регламент о требованиях пожарной безопасности» / Парламентская газета, № 47-49, 31.07.2008.

8. Федеральный закон от 21.07.1997 № 116-Ф3 (ред. от 19.07.2011) «О промышленной безопасности опасных производственных объектов» / Российская газета, № 145, 30.07.1997.

9. Федеральный закон от 10.12.1995 № 196-ФЗ (ред. от 19.07.2011) «О безопасности дорожного движения» / Российская газета, № 245, 26.12.1995.

10. Закон РФ от 20.08.1993 № 5663-1 (ред. от 30.12.2008) «О космической деятельности» / Российская газета, № $186,06.10 .1993$.

11. http://www.undp.ru/index.php?iso=RU\&lid=2 